\title{
Action on Sustainable Forest Management through Community Forestry: The case of the Wetzin'kwa Community Forest Corporation
}

\author{
by Anderson Assuah ${ }^{1 \%}$, A. John Sinclair ${ }^{1}$ and Maureen G. Reed ${ }^{2}$
}

\begin{abstract}
Community forestry is a collaborative governance approach to forest management that is seen as a promising tool for implementing sustainable forest management. The expectation of government is that community forests, as managers of public forestlands, will work to achieve sustainability. Little has been written, however, about the ways community forests are being managed in an effort to realize this goal. This paper considers how the Wetzin'kwa Community Forest Corporation (WCFC) in British Columbia is working to sustainably manage its community forest. The study identified efforts taken by the WCFC towards achieving sustainable forest management as perceived by participants, and considered these in relation to indicators established by the provincial government and the Canadian Council of Forest Ministers. The results reveal that WCFC is making progress towards sustainably managing the forest by taking action on issues such as local employment and protecting cultural values. However, it is difficult to make a definitive statement as to whether these efforts are modest or advanced, partly because the WCFC has not developed a set of criteria and indicators to measure its own performance, and also due to the lack of a clear framework from government for measuring the achievements of such small-scale forestry operations in relation to sustainability.
\end{abstract}

Key words: sustainable forest management, community forestry, criteria and indicators, British Columbia, Canada.

\section{RÉSUMÉ}

La foresterie communautaire est une forme d'approche de gestion collaborative en aménagement forestier qui aurait du potentiel comme outil d’aménagement forestier durable. À titre de gestionnaire du domaine forestier publique, le gouvernement s'attend à ce que les forêts communautaires sorientent vers la durabilité. Il y a peu décrits sur la façon d’aménager les forêts communautaires aménagées dans la poursuite de cet objectif. Cet article s'intéresse à la façon dont la Wetzin’kwa Community Corporation (WCFC) de la Colombie-Britannique seefforce d’aménager sa forêt communautaire de façon durable. Létude fait ressortir les efforts déployés par la WCFC pour atteindre un niveau d’aménagement forestier durable tel que vu par les participants et les a comparés aux indicateurs retenus par le gouvernement provincial et le Conseil canadien des ministres des forêts. Les résultats indiquent que la WCFC sachemine progressivement vers un aménagement durable de la forêt en agissant sur des enjeux comme le niveau demploi local et la protection des valeurs culturelles. Il est toutefois difficile d'établir de façon claire s'il s'agit d'efforts modestes ou majeurs, notamment parce que la WCFC n'a pas élaboré de critères ni d'indicateurs pour mesurer sa propre performance et vu l'absence d'un cadre gouvernemental précis dévaluation des réalisations en matière de durabilité pour des opérations forestières à petite échelle.

Mots clés : aménagement forestier durable, foresterie communautaire, critères et indicateurs, Colombie-Britannique, Canada

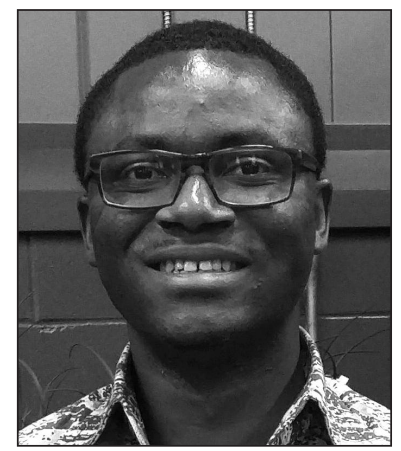

Anderson Assuah

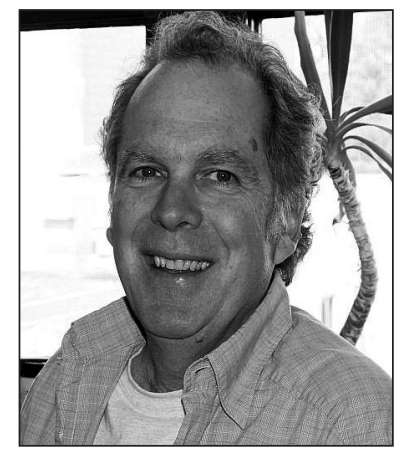

A. John Sinclair

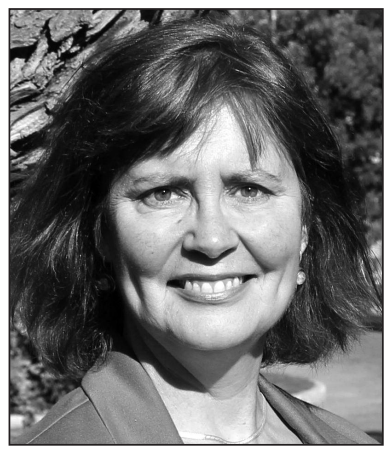

Maureen G. Reed

\footnotetext{
${ }^{1}$ Natural Resources Institute, University of Manitoba, Winipeg, MB R3T 2N2

${ }^{*}$ Corresponding author e-mail: assuaha@myumanitoba.ca.

${ }^{2}$ School of Environment and Sustainability, University of Saskatchewan, Saskatoon, SK S7N 5C8.
} 


\section{Introduction}

New approaches to forest governance have arisen from the public criticism of forest management and regulation in Canada (e.g., Charnley and Poe 2007) and demands for greater accountability from the forest sector (Bullock and Hanna 2008). Provincial governments tested different models that could increase public and stakeholder involvement in forest management (Parkins et al. 2006) and enhance the social, ecological and economic sustainability of forestry (Charnley and Poe 2007). Community forestry has emerged as an approach to forest management that devolves some decision-making authority to local communities, aims to increase local benefits derived from forest use, while encouraging the sustainable management of forests (Baker and Kusel 2003, Teitelbaum 2014). The emergence of community forestry signifies a shift in forest management rights and responsibilities, such as use, control and accountability, from the state to local people (Teitelbaum et al. 2006).

According to Baker and Kusel $(2003$, p.8) the objectives of community forestry are to "conserve or restore forest ecosystems while improving the well-being of the communities that depend on them." In theory, the involvement of local people in forestry decision-making processes leads to improvements in the wellbeing of stakeholders and communities, and the health and value of the forest (Duinker et al. 1994, Alemagi 2010). There are, however, some significant limitations of community forestry in achieving these ends. For example, it might 'institutionalize conflict' if the model incorporates stakeholders with irreconcilable differences in a single management body (Beckley 1998). Additionally, Bradshaw (2003) identified capacity challenges, such as securing start-up capital, that new managers of a community forest (CF) need. Duinker et al. (1991) also cautioned that CFs cannot be perceived as a one-size-fits-all model, because not all communities have the capacity required to embrace the approach, especially in terms of maintaining healthy ecological conditions.

Despite these issues, advocates of community forestry emphasize its potential to achieve sustainable forest management (SFM), a concept that has become a normative goal for forest management, particularly in Canada. The Canadian Council of Forest Ministers defined SFM as forestry that "maintains and enhances the long-term health of forest ecosystems for the benefit of all living things while providing environmental, economic, social, and cultural opportunities for present and future generations" (Canadian Forest Service 2001, p.38).

While there continues to be discussion around community forestry in a Canadian context, little has been written about its practice and outcomes in relation to SFM (Furness et al. 2015). Recognizing this, Teitelbaum (2014) developed a set of criteria and indicators (C\&I) to consider the outcomes of CFs in Canada in three specific areas: participatory governance, economic benefits, and multiple use forests. More recently, Furness et al. (2015) evaluated the CF Program in British Columbia $(\mathrm{BC})$ by measuring progress against the original aims of the program. Teitelbaum $(2014$, p.265) concluded: "The lack of empirically based accounts of CF practice represent a limitation from a policy perspective, as decision-makers have few studies to draw on in gauging the potential of this approach."

While these works provide important insights about assessing the outcomes of community forestry practice in
Canada, there is a clear need for more analysis on the progress of such forestry, and its contribution to SFM goals. With this in mind, our research examines the perspectives of those involved in community forestry regarding how they are working to sustainably manage the forest, so that we can identify approaches for advancing SFM in this context. Our focus was the Wetzin'kwa Community Forest Corporation (WCFC), located in Smithers, BC. The licence for the WCFC is jointly held by the Town of Smithers and the Village of Telkwa, and collaboratively managed with the Wet'suweten First Nation (FN) and other forest resource users as outlined below.

\section{Sustainable forest management}

Foundational thinking about SFM is usually attributed to the 1992 United Nations Conference on the Environment and Development (UNCED) in Rio, which provided the platform for discussing management and preservation of both timber and non-timber values associated with forests (McDonald and Lane 2004). Wijewardana (2008) asserted that prior to the Conference, forest management was dominated by the principle of sustained yield ${ }^{3}$, resulting in the degradation or loss of significant ecological, social, and economic values of the forest. SFM was a response to the concept of sustained yield, drawing attention to the full range of values forests provide rather than simply the fibre they produce (Canadian Council of Forest Ministers [CCFM] 2008).

Today SFM has become a central goal for forest management in Canada. Progress towards SFM is usually measured and assessed against a set of C\&I developed to monitor values in managed forests (e.g., BC Ministry of Forests, Mines, and Lands (MFML 2010). C\&I provide knowledge and information about forests, with the results contributing to national and international reports on the state of forests (Sherry et al. 2005). Criteria provide information on the range of forest values being measured, such as biological diversity, while indicators are measurable characteristics of these values (see Natural Resources Canada (NRC) 2012). Indicators of biological diversity, for instance, can include genetic diversity, ecosystem diversity, and species diversity (CCFM 2006).

Through a public consultation process with federal, provincial and territorial governments, experts from industry, academics, and others, the CCFM developed a set of C\&I in 1995 for tracking the country's progress towards SFM (Hickey and Innes 2008). What started as six criteria with 83 corresponding indicators underwent a review in 2001 and now consists of six criteria and 46 indicators (CCFM 2006). Similarly, in order to document advancement towards SFM at the provincial level, BC tracks and reports on SFM using its own set of indicators. These selected indicators are based on "those found in national level SFM criteria and indicators..." (MFML 2010 , p. 14). Following revisions since the first publication, the state of BC's forest is now assessed and monitored using 91 indicators grouped into 24 topic areas (MFML 2010).

Although emphasis has been placed on using C\&I to measure SFM, this approach comes with its own challenges. For instance, C\&I are often criticized for their positivistic, top-down, and reductionist nature (Sherry et al. 2005, Pokharel et al. 2015), which does not allow them to ade-

\footnotetext{
${ }^{3}$ The principle of sustained yield: The volume of wood harvested should not exceed the volume of growth gained over a given period of time.
} 
quately account for the complexities of forest systems (Bass 2002). Sherry et al. (2005, p.513) see this as leading to a failure to "capture many C\&I of critical importance to local populations... who have their own definitions of sustainability," particularly because they are often developed in a top-down fashion, and mainly by experts.

Globally, bottom-up C\&I are slowly developing as selfmonitoring tools for community-based forest initiatives, such as CFs (Pokharel et al. 2015). For instance, Pokharel and Suvedi (2007) report that CF user groups and forest technicians collaboratively agreed on 17 indicators-including availability of non-timber forest products, wildlife, and amount of community funds-to measure the success of the CF program in the mid-hills of Nepal. Similarly, Furness et al. (2015) reduced the components of the BC community forest initiative into three main areas to enable assessment of the program: economic benefits, diversification and innovation; environmental stewardship and management of the forest for multiple values; and social benefits, including community involvement and participation. Developing such local-level indicators can be time-consuming, expensive, and tedious (Teitelbaum 2014); however, it can result in "...sharing local and scientific and other external knowledge and guiding action towards the sustainable management of forests" (Ritchie et al. 2000, p. 11).

In $\mathrm{BC}$, the indicators for SFM developed by the Province are available for use by CFs such as WCFC as a way to direct, track, and measure their action on sustainability. In our analysis, we considered these indicators and looked at how well the CF is taking action on them. In order to provide as much breadth as possible in terms of respondents' perspectives on SFM, we also used the C\&I of SFM developed by the CCFM, and tracked the outcomes of the frameworks used by Teitelbaum (2014) and Furness et al. (2015) to assess CF in Canada and $\mathrm{BC}$ respectively.

\section{Context}

The Canadian provinces of BC and Quebec have established legal tenures for CF (Teitelbaum 2014), while Nova Scotia has one pilot $\mathrm{CF}$ initiated through a legal license agreement with the Province. The Community Forest program in BC awards area-based forest tenures to communities to manage and benefit directly from forest activities on local forest lands. The program is intended to provide "new opportunities for community management of Crown forest land" and "greater flexibility" to communities in managing local forests in the province (British Columbia Ministry of Forests, Lands and Natural Resource Operations [MFLNRO] 2014).

In 2007, the WCFC was awarded a five-year Probationary Community Forest Agreement, to manage a 32000-hectare forest. A permanent CF licence was awarded in 2010 for a 25year renewable period. The WCFC was chosen for study based on several criteria, such as evidence of an on-going process of multi-stakeholder collaboration in forest management, a decision structure that allows representation of the larger community on the Board and committees, and evidence of an ecosystems-based management approach to SFM since its inception. In addition, we observed that just prior to fieldwork, WCFC had a lot of upcoming activities, including road building, ecosystem classification, site plan formulation, silviculture prescriptions, and an Annual General Meeting.
These activities provided opportunities for first-hand observation of SFM operations and helped WCFC stand out from the other $\mathrm{CF}$ under consideration.

The WCFC is governed by a seven-member volunteer Board that oversees the Corporation's strategic planning. There are four permanent seats on the Board: the town of Smithers; the village of Telkwa; the Office of the Wet'suwet'en, representing the Wet'suwet'en FN; and Northern Engineered Wood Products, an industry representative. The first three representatives are considered main stakeholders of WCFC, but Telkwa and Smithers are the two actual shareholders of the CF tenure. Each own $50 \%$ of the shares. The remaining three seats are held by members of the public, often referred to as director-at-large members who sit for a three-year term. Members of the public interested in becoming director-atlarge members must apply to the Board to be selected. While the Board is responsible for the strategic planning of WCFC, Silvicon Services Inc., a local forestry company, has been contracted to oversee the operational and day-to-day management of the forest. The company takes direction from the Board and also provides feedback on operations to the Board.

\section{Method}

This research is a qualitative case study (Thomas 2011) making use of four methods of data collection: semi-structured interviews, participant observation, document review, and guided forest visits. The lead author lived in Smithers from October to December 2013 in order to lead the fieldwork. He conducted thirty interviews, the majority (25) being face-toface, while five were completed by telephone. Interviews continued until data saturation was reached-that is until the interviews no longer revealed fresh insights (Creswell 2014). In twenty-five instances, interviews were recorded while hand-written notes were taken at the request of five participants. Participants interviewed included present and past WCFC Board members (11), people involved in the management of WCFC (2), members of forest user groups (7), a community researcher, land/property owners (2), past district forest managers (2), founding members of the WCFC (2), a Councillor from Telkwa, a contractor, and an executive of the Office of the Wet'suwet'en. The interviews explored the personal experiences of participants involved with WCFC, particularly in regards to their perspectives regarding the implementation of SFM, and documented their experiences and knowledge around local management of the CF tenure (Creswell 2014).

Participant observation was used to document activities of the WCFC in order to help corroborate what participants said during the interviews (Yin 2003). The lead author attended and took notes at the Annual General Meeting of the WCFC, held in Moricetown on a traditional territory of the Wet'suwet'en FN. He also undertook three guided forest visits to observe forest practices that participants identified as generally supporting SFM and forest management practices. The first visit was with the WCFC's forest manager; the second was with a Silvicon Services Inc. employee who supervised contractors operating within the WCFC's tenure; and the last was led by a community researcher. On these forest tours, field notes and photographs were taken and formed part of the study's data. In addition to the above fieldwork methods, the lead author reviewed the organisation's documents. These 
included: annual reports, the memorandum of understanding with forest user groups, the 2013 financial statement, the forest stewardship and management plan, and WCFC's policies from 2010 to 2015.

Semi-structured interviews and field observation notes were recorded and transcribed, and organized into themes with the aid of NVivo (QSR 2010) software. The data analysis involved sorting and coding data segments and identifying themes (Creswell 2014) in NVivo (QSR 2010) in relation to the four main SFM themes, including ecological sustainability, social sustainability, economic sustainability, and cultural sustainability. These themes were created based on the responses provided by participants, and the key themes of SFM as noted in the literature. We started the analysis with three themes-ecological, economic, and social sustainability-which are well documented in the literature (e.g., Sherry et al. 2005). The fourth theme, cultural sustainability, was identified since it was clearly evident in the data provided by respondents, and because of the implications of forestry on local cultural values-particularly Aboriginal cultural values-in our study area. The sixteen sub-themes displayed in Table 1 that relate to each of these main themes all emerged from, and are grounded in, the data collected. We then considered the sixteen sub-themes, capturing participants' perspectives on action being undertaken to achieve SFM, against BC's SFM goals, the CCFM C\&I, as well as indicators specific to CFs identified by Teitelbaum (2014) and Furness et al. (2015). We did this by looking for overlap between the SFM outcomes as indicated by WCFC participants (e.g., public participation) and the criteria and indicators of SFM sug-

Table 1: Major themes and sub-themes of SFM from the WCFC

\section{Ecological sustainability}

- Integrated resource management (IRM) initiative

- Biodiversity (e.g., encourage species diversity)

- Wildlife management (e.g., wildlife patches left)

- Watershed/Riparian area management (e.g., exceed watershed plan standards)

- Forest understory management (e.g., snags left standing)

- Timber harvesting (e.g., winter harvest)

- Tree planting (e.g., 1.7 million trees planted)

\section{Economic sustainability}

- Local employment initiatives

- Legacy fund created

- Silvicultural accrual fund created

\section{Social sustainability}

- Participation by forest user groups and affected individuals

- Active First Nation (Wet'suweten) involvement

- Working directly with multiple users (e.g., recreation users)

- Supporting local initiatives through grants

\section{Cultural Sustainability}

- Protecting and managing for Wet'suwet'en values through involvement in tenure management

- Management of non-timber forest products (NTFPs) gested by these documented sources. The data from participants in quotes represent the views of the majority of respondents and best represent those views, unless otherwise indicated. To comply with our ethics approval, the names of participants are not provided; instead, each different respondent has been given a unique number.

\section{Working towards SFM - Results}

Following Table 1, the results are presented under the four major themes. Quotes from participants highlight their experiences with the WCFC and their perspectives on how the CF is achieving SFM.

\section{Ecological Sustainability}

Proponents of the community forestry approach have often indicated that maintaining ecological integrity can be achieved when communities are involved in managing the forest. This idea was shared by participants, who perceived that the WCFC was managing the forest in an ecologically sustainable manner. Participant 1 highlights this in the following:

Our AAC is sustainable; our annual growth exceeds what we are taking out; large areas are left as core ecosystems [not harvested]; [there are] mountain goat habitat areas, where no harvesting occurs, and riparian zones, which we have $70 \%$ retention. This forest, habitat types, wildlife, and fishes can operate for a very long time.

Interviews with participants, and a review of the documents, both revealed that the WCFC's Integrated Resource Management (IRM) initiative was directed at ensuring forest health and resiliency, among other goals. The initiative was spearheaded by a past Board member who, when on the Board, believed things should be done differently from the way local forest industries operated in the past. Specific actions outlined in the IRM initiative include: whitebark pine (Pinus albicaulis Engelm.) recovery; planting of western larch (Larix occidentalis Nutt.) and Douglas-fir (Pseudotsuga menziesii Mirb.) in anticipation of climate change; improving stocking standards; and funding grant proposals that might promote or improve forest ecosystems or SFM.

During the 2012-13 season, for example, the WCFC supported a researcher from the Bulkley Valley Research Centre (BVRC), a local research organisation, to implement a whitebark pine recovery project in the area. It also provided planting sites on the CF tenure. Whitebark pine recovery was established as a goal "because it is an endangered tree. It is red-listed across Canada and it occurs naturally here, so it is important to do what we can to restore it" (Participant 10).

Interviews and site visits also revealed WCFC's collaboration with the College of New Caledonia (CNC) and the Northwest Community College (NWCC) on a climate change experiment on the $\mathrm{CF}$ landbase, in which western larch, Douglas-fir, and western redcedar (Thuja plicata Donn ex D. Don) were to be planted to assess their ability to adapt to climate change. The planted species, we were told, will be monitored for survival and overall health in their 'new' surroundings, and the knowledge gained through the experiment will help improve forest management by planting species more resilient to climate variability. 
In addition to these efforts, there are some common components/markers of ecological sustainability, such as management of wildlife, riparian/watersheds, and biodiversity (see: MFML 2010), that forest licensees in BC are required to monitor. These markers were all raised by participants in the interviews as examples of advancing ecological sustainability.

\section{Biodiversity}

Participants mentioned that WCFC plants different tree species appropriate to the ecosystem of the Bulkley Valley, namely lodgepole pine (Pinus contorta Dougl. ex Loud.), Engelmann spruce (Picea engelmannii Parry ex. Engelm.) and Balsam Fir (Abies balsamea L.). "We try to plant the range of species ecologically suited to this site, and that is defined by government, but we will also leave commercial and non-commercial size trees..." (Participant 3).

Furthermore, the Wet'suwet'en shares with the WCFC information on rare species to help manage for biodiversity.

The Wet'suwet'en has done an analysis on their landbase and determined ecosystems that are rare... . We have created one that is unique to this area, and it is shared with the general manager to ensure that we are not focusing on harvesting activities in areas with such rare species or medicinal plants (Participant 2).

\section{Wildlife Management}

Participants indicated that the WCFC adheres to the rules set out for wildlife management in both the Bulkley Land and Resource Management Plan ${ }^{4}$ (LRMP) and Forest and Range Practices $\mathrm{Act}^{5}$ (FRPA) of BC. For example, we were told that WCFC encourages young willow growth for wildlife (e.g., for moose browsing), and deactivates winter roads to reduce access to wildlife hunting in the summer and fall.

During a guided forest visit, a tour guide explained that areas where wildlife patches had been left after logging was one way the WCFC manages for wildlife. Some participants and all three tour guides mentioned that there are core ecosystems within the landbase that have been delineated by the LRMP and are protected by the WCFC. "Large areas are left as core ecosystems [not harvested]" explained Participant 1.

In addition, some participants and the second guided tour revealed that wildlife management is mapped up when determining where to log: "I think it [wildlife management] is in the planning... Your goal for clear-cutting and distribution should fit well in the landscape, leaving mature cover in the landscape in order not to disrupt wildlife" (Participant 3). This guide also pointed to a wildlife corridor on the landbase that had been purposely left for wildlife, such as moose and mountain goats. A review of WCFC's 2013 Logging Plan Map also revealed that wildlife tree retention areas were left out of the areas to be harvested as a way of managing for wildlife.

\footnotetext{
${ }^{4}$ Bulkley Land and Resource Management Plan: This is a subregional land management plan that guides the management of land and resources in the Bulkley Valley.

${ }^{5}$ Forest and Range Practices Act: This is the provincial legislation that guides forest and range management in British Columbia.
}

\section{Watershed/Riparian Area Management}

Participants noted that watersheds/riparian areas are particularly important to residents in the Bulkley Valley, as they are major sources of water. Through the Bulkley LRMP there have been limits set on the level of harvest that can be done within the reach of a watershed or riparian area. Participants said that this requires careful management of watersheds within the CF landbase. In addition, collaboration with the Wet'suwet'en has resulted in managing watersheds and riparian areas beyond the requirements of both the LRMP and FRPA. Participant 1 explained, "our riparian management areas are wider and broader than what is provided for [in the LRMP]. We have signed a memorandum of understanding with the Wet'suwet'en, who want wider management." Participant 11 also revealed that "for instance, leaving a buffer around an area may not have been stated [in the LRMP], but the General Manager finds it necessary to do so for increased protection and everyone agrees on that."

\section{Tree Retention}

During the second guided tour, which coincided with active logging, the lead author observed that not all trees on a cutblock were cut, even though clearcutting is the dominant approach to harvesting. The trees left behind were not merchantable on some cut-blocks, but on others merchantable trees were left. These trees were identified as good for protecting understory and were left intentionally. Maintaining understory constitutes the biggest component of WCFC's management "because we are paying our loggers to retain it. On each cut-block, we are retaining saplings, poles, and trees that are not targeted, namely, balsam fir and spruce" (Participant 1).

Some participants agreed with Board members that there was understory management. "They are keeping some of those [understory plants], but I think it is because the CF is close to the ski club, so everyone is watching, and they don't want everywhere to be flat" (Participant 15). However, two participants were not convinced. One explained, "they will tell you there is retention, but that is very little. When they do the prescription, what is left in most places is a very small amount of trees. To me, it is unsightly and, if there was a different way to do it and leave a greater amount of trees, that would be a better practice" (Participant19).

\section{Timber Harvesting/Soil}

We were told that logging is done mainly during the winter season, because there is less impact from harvesting on the land/soil. According to Participant 10, "we [WCFC] do winter logging... The soil layer is undisturbed, because there are no skid trails. Soils are also a requirement in the Forest Stewardship Plan, and there is $5 \%$ or $10 \%$ disturbance depending on the kind of soil [impacted]".

Some participants expressed satisfaction with clearcutting as the main method of harvesting, because "at least the community forest tries to make it [clearcuts] less visible and less impactful" (Participant 16) in comparison to work carried out by large industrial companies.

A contractor explained that harvesting “...is a mixture between clearcut and selective logging. By selective logging, you will still leave merchantable trees behind if you are not after that particular species. Some places are left behind, 
because they are wetlands, culturally modified trees (CMTs), cultural trails, or too sensitive" (Participant 30).

Even though the Board had discussed carrying out more selective logging, it was explained that "it isn't conducive to do selective logging right now, because the beetle infestation is about $70 \%$ on our area, so our license directs us to those areas" (Participant 2).

One participant's contrary view was that selective logging could be done when salvaging pine-infested wood, particularly when fines are attached to logging contracts.

\section{Tree Planting}

Reforestation is a critical part of forestry regulations in BC and central to SFM at WCFC. Documents indicate that tree planting on the CF is usually from June to August each year. Since the inception of the CF in 2007 until 2013, WCFC has planted over 1.7 million trees (Notes from AGM). "WCFC plants trees as soon as they harvest, fulfilling silviculture responsibilities. They are responsible for trees until they are free to grow, which is a minimum of five years. In that respect, they are doing a good job for sustainable forestry" (Participant 30).

\section{Economic Sustainability}

One expectation of community forestry in the literature is the provision of economic benefits to local communities (e.g., Teitelbaum et al. 2006). Participants indicated that in the early days of WCFC, they learned about some of the benefits that the community could enjoy from the Corporation if it were successful, including support for local initiatives and monetary benefits. "Originally, it [WCFC] was set up to provide additional income to the community through harvesting timber and taking care of the land" (Participant 29).

The WCFC has established funds that aim to ensure longevity of their operations and benefits to the community. One way the Board has done this is by establishing an annual grants program to distribute profits to the public. These grants support community projects and initiatives in areas such as recreation, social services, and the environment (http://www.wetzinkwa.ca/grant-program.html). In addition to the grants, monetary donations have been given to Smithers, Telkwa, and the Wet'suwten.

To ensure the sustainability of the grants program, WCFC established a Legacy Fund, which aims to "bank money to draw a lot of investment income from, so we are able to maintain a steady grants program to keep some stability" (Participant 4). The WCFC expects to use profits they generate from investing this money to continue funding the grants program year after year: "The fund has been around for about three years. This will prevent us from depending on logging [profits], because there are years we wouldn't be able to harvest much" (Participant 2).

A Silviculture Accrual Fund provides funds for silvicultural operations. The Board has set aside $\$ 4.50 / \mathrm{m}^{3}$ of harvested wood in this Fund, and will use the accumulated monies to support silviculture treatments on its landbase into the future. "...we have funds for our silviculture activities, which may last for up to 12 years... every time we harvest, we have money to re-forest in the next 15 years plus more. We are a little conservative as a Board, putting down more money than we require" (Participant 3). A Board member also explained that an Emergency Fund has been set up by the Board that, in the event of any catastrophe, would be utilised to defray administrative costs and help the organisation make its way back to active operations.

The WCFC also contracts activities in the forest to people within the Bulkley Valley, particularly within the jurisdictions of Telkwa, Smithers and the Wet'suwet'en. For example, Aboriginal contractors were awarded beetle management contracts to undertake beetle probing and burn activities in the 2008/2009 season (WCFC End Year Summary 2008/2009). Contracts for tree planting and logging operations are also awarded to local contractors, while logs are sold to the mill in Smithers.

Board members also underscored the importance of learning how to run the WCFC as a profitable forestry business in order to remain economically sustainable. One Board member explained:

For example, if the log market is low, we have to do things differently to make ends meet. As things go up then you have opportunities to do different harvesting, different applications over and above planting because, at the end of the day, we have to make sure that we are going to do business to stay here for a very long time (Participant 4).

\section{Social Sustainability}

Involving the Wet'suwet'en during the planning stages of the CF licence application is an action participants identified as encouraging social sustainability:

...Smithers and Telkwa approached the Wet'suwet'en before there was any application for CF licence, and that made a huge difference for our [Wet'suwet'en] leadership, because it was an opportunity to create something. When projects are presented to the Wet'suweten with strict structures, there is no room for our principles and values to be incorporated, so the big difference was we created the CF with the municipalities (Participant 2).

The Wet'suwet'en's involvement in the CF has resulted in an arrangement with the WCFC where the former makes changes in operational plans before the implementation stage. Primarily, this is a way to check against destroying Wet'suweten cultural values, medicinal plants, traditional trails:

To a certain extent, the Wet'suwet'en is in a unique position in that the GM develops the cutting permits and...we have a referral coordinator that gets to see the operational plans of the community forest before they are formalised, and gets to make changes... The referral coordinator, through the Wet'suwet'en, provides a letter of support to the plans once everything is okay (Participant 2).

Additionally, the WCFC works with and supports local recreational groups whose activities are within its landbase, even though it does not directly manage for recreational values. In order to respect and incorporate the views of forest user groups into management plans, the WCFC has signed memorandum of understanding with groups whose activities might be affected by forestry operations, including the Smithers Community Forest Society (SCFC), Smithers 
Mountain Bike Association (SMBA), and the Bulkley Valley Cross Country Ski Club (CCSC). The WCFC resource user group meetings give these organizations the opportunity to express their views and provide input on management plans.

Some recreational groups commented on the positive working relationship that has evolved between themselves and WCFC. They expressed satisfaction with WCFC's activities, particularly on the landbase, and are pleased that they can offer input into management decisions that directly affect them: "Anything that affects us, we have an influence. When they are cutting, we talk to them about the kind of finishing they should leave behind. We have talked to them about what areas they would cut, and their ability to remove dangerous trees" (Participant 2).

However, participants suggested that the efforts to engage the broader public in management of the CF has been poor. They pointed to inadequate engagement between the WCFC and the public, and insufficient community education on its management and activities. In addition, the Corporation does not provide information on annual general meetings, yearly management plans, and minutes of Board meetings on its website to allow the public to learn from its activities, or to obtain public input into management. This lack of communication makes it very difficult for the general public to get involved in managing the CF. Groups that are directly affected by the operations of WCFC (e.g., forest user groups and property owners) have many more opportunities than the general public to participate in the management of the $\mathrm{CF}$.

\section{Cultural Sustainability}

Participants revealed that the Wet'suwet'en FN plays a large role in protecting their cultural and medicinal plants on the landbase before any cutting by WCFC occurs: "They [Wet'suweten] are into picking berries and those kind of things... and they come forward and say those areas we are planning to log have a good concentration of mushroom, so is there something we can do not to damage it" (Participant 5). Participant 1 also explained, "the Wet'suweten is participating in forest tenure management on their territory, and they have direct impact on what is happening...they wanted a big buffer for goat habitat and they have it, a bigger buffer around streams and they have that."

In order to ensure that cultural and medicinal values are well protected, the Wet'suwet'en indicated they share information with the WCFC:

One other thing we have done is to GPS our trail system and, if there are forestry activities around the trail system, the WCFC ensures that when the plantation is planted, our trail is not going to be reforested. So when the next forest comes up, the trail network will still be functional, and that is a lot different from the normal licensee, who plant the whole structure and the whole trail system is lost. Another example is that there are culturally modified trees that we take time to GPS, so they are protected on the landbase after forest activities - that is another difference with other major licensees, who would not take the same precaution like the WCFC will do (Participant 2).

In expressing satisfaction with the arrangement between the Wet'suweten and the WCFC in managing cultural values, a Wet'suwet'en participant noted: "We have been trying to promote the conservation and protection of our cultural heritage resources and valued ecosystem layers, but with the major licensees we don't get the same results as we have with the WCFC" (Participant 23). Another participant from the Wet'suwet'en FN mentioned that they had concerns over whether information shared was going to be used by the CF in its management, but has observed that the information is utilised: "...we [Wet'suwet'en] have seen that; they have demonstrated that [use of the information] in the forest practices" (Participant 23).

To some participants, collaboration with the Wet'suweten and efforts at preserving their values shows that SFM practices are being applied on the land. "In terms of preserving some of Wet'suweten values and interests on the landbase, that is making practices sustainable" (Participant 2). "The representative from the Wet'suwet'en [on the Board] was involved to ensure that things that we were going to do were sustainable" (Participant 12).

The WCFC has also financially supported the Wet'suweten (who maintain the rights to harvest NTFPs) to research the propagation of huckleberries and blueberries, which are of cultural significance. The research involved growing the plants in a greenhouse and assessing their survival rates. If the propagation was successful, the huckleberries and blueberries were to be planted on the landbase. However, the trial did not yield the results needed to allow planting to commence. Supporting the Wet'suweten in managing NTFPs started when logging began on the CF landbase:

We [WCFC] created a fund that went into supporting them in identifying their native products they take from the ground... The way the Board works as a unit and involving the $\mathrm{FN}$ in the process, setting aside money for the FN to investigate and determine what the undergrowth is after logging struck me as unique (Participant 13).

In addition, the WCFC has been helpful in surveying areas on the landbase that are likely to enhance berry growth. "The WCFC hired a Wet'suwten local contractor to do some surveys, where there are productive berry stands and regenerating forests... When it is time to do some silviculture treatments, we can do some practices that are conducive to enhancing berry production" (Participant 2). Board members stated that there was a conscious effort to avoid harvesting in areas considered to be important habitats for NTFPs: "...There have been areas where maybe the GM says we will $\log$ in here and the Board member from the Wet'suweten says this is our traditional mushroom area and we just leave it" (Participant 5).

\section{Contextualizing SFM Outcomes}

The data show that study participants think that through its operations and activities, the WCFC is contributing to achieving SFM. One way to gauge these contributions is to consider the actions outlined above against SFM indicators from BC and the CCFM C\&I, as well as indicators from studies conducted by Teitelbaum (2014) and Furness et al. (2015). It should be noted that the SFM indicators established by BC and CCFM are not particular to any type of forestry or forestry licence; they are applied to all forestry activities 
whether community-based or industrial. On the other hand, the indicators developed by Teitelbaum (2014) and Furness et al. (2015) are more specific to considering the outcomes of CF in Canada and $\mathrm{BC}$, but the authors did not establish these as a baseline for considering SFM in a CF context. Table 2 highlights the indicators from these institutions and studies that overlap with the SFM outcomes at WCFC. For instance, biodiversity and water/riparian zone management are themes that run through SFM indicators from BC and the CCFM C\&I and are being addressed by the WCFC. Also, providing employment-a key indicator from these institutions and the two CF outcome studies-was also noted as an outcome by WCFC participants (Table 2). Other areas of overlap and the actions reported by WCFC participants relate to public involvement and FNs involvement in forest management.

Public involvement as an indicator is reflected through the opportunities provided to forest user groups, and those affected by the WCFC activities, to provide input into decisions and to affect management plans. This action is in line with Teitelbaum's (2014) indicator, "local participation in design of decision-making process" (Table 2) and Furness et al.(2015) criterion, "community involvement and participation" (Table 2). As a criterion, inclusion of forest stakeholders on a board (Table 2) used by Teitelbaum (2014) does not apply to the WCFC, because the Board structure does not allow for such representation. However, WCFC's Board is made up of members from the local community, which is in line with the indicator noting that a proportion of a board should be derived from the local community (Teitelbaum 2014). These notwithstanding, Teitelbaum (2014) and Furness et al. (2015) conclude in their studies that there is no ideal governance model for CF.

In addition, satisfaction with forestry activities is a very important consideration related to public involvement in BC (Table 2). The WCFC is achieving this, at least among key forest users operating on its landbase. As discussed by Beckley (1998), CFs are challenged to maintain stakeholder involvement and the broad range of interests that their stakeholders represent. Towards meeting this challenge, the WCFC has worked with, and gained the support of, forest user groups. However, the WCFC falls short in providing adequate information to the public on its website and involving the broader public in WCFC management and other activities. Involving the public in meaningful ways is central to effective resource governance generally, and forest management specifically (McGurk et al. 2006). This aspect of local management practice requires greater attention by the WCFC, especially since the CF agreement requires them to regularly engage the broader public (Furness et al. 2015). The data do show that the WCFC does organize events-such as walks in the woods and the AGM-to inform and 'draw' the public into its activities, though participation is usually minimal. This echoes Furness et al.(2015) findings that getting the public to events organised by $\mathrm{CF}$, and sustaining their participation is a challenge.

A measure of SFM in $\mathrm{BC}$ is the involvement of FNs in forest management (Table 2). Also, the CCFM indicator, "Extent of Consultation with Aboriginals in Forest Management Planning..." (Table 2), reflects a concern for ensuring that Aboriginal people are involved in management planning. Likewise, Teitelbaum (2014) sees "active support of Aborigi- nal peoples in identification/protection of cultural values" (Table 2), as an indicator that measures FNs involvement in CF. The WCFC is clearly taking action on these indicators by involving the Wet'suweten in decision-making and forest planning; allowing them to make changes and approve of harvesting plans before they are applied on the landbase; and protecting their cultural values and medicinal plants. These are important strides by the WCFC, given that industrialscale forest management in Canada is often criticised for not adequately incorporating Aboriginal values in decisions that affect Aboriginal people (Adam and Kneeshaw 2009). For example, Furness et al. (2015) reported that only 14 of 38 CFs they surveyed had Aboriginal-led boards or partnerships with Aboriginal peoples.

The close working relationship between WCFC, the Wet'suweten and forest users indicates an openness to ideas and suggestions that could benefit the Corporation. With such an approach, the WCFC can improve or enhance its management of the CF, both on the landbase and in its relationships with other organisations. For example, the Wet'suweten has shared critical information with the WCFC about managing the forest. Uncertainties surround forest management, as they do any other natural resource (Berkes 2009). Incorporating different sources of information from groups affected by forest management decisions can be critical to achieving SFM and sustainability in general.

Regarding the economic component of SFM, two important indicators measured in BC and echoed by Teitelbaum (2014) and Furness et al. (2015) in their studies include the number of jobs that rely on the forest and the incomes based on the forest (Table 2). The WCFC has acted on these indicators. It has a $100 \%$ local hiring policy for all operations, including logging, tree planting, and related contract work. We were told that the WCFC aims to create reliable job opportunities and sources of local income. This supports Teitelbaum (2014) and Furness et al. (2015), who also found local employment to be an important component of $\mathrm{CF}$ governance in Canada. A survey conducted on sixteen CFs by the BC Community Forest Association revealed that on average they created " 0.3 full time jobs $/ 1000 \mathrm{~m}^{3}$," an employment rate deemed to be " $50 \%$ higher than the industry average" (BCCFA 2015, p.3). However, we were unable to ascertain the exact number of spin-off jobs created by the WCFC to determine precisely the number of local jobs created and the overall impact of this in a community context.

Beyond jobs, the WCFC aims to address economic sustainability through its annual grants program that distributes benefits locally. In this way, it aims to address CCFM indicator, "Distribution of financial benefits from the timber products industry" and Teitelbaum (2014)'s indicator, "Annual dollars donated to local projects and initiatives" (Table 2). The WCFC provides these funds to local non-profits to support their activities. Given that distributing profits is a significant goal of CF (Teitelbaum 2014), the establishment of a Legacy Fund for such purposes by WCFC is a signal that they plan to continually distribute monetary benefits to the community, even in years when no profits are made on operations, or when profits decline. The sixteen CFs in the survey were reported to have assisted community projects, on average, with about $\$ 100000$ annually in cash and in-kind support (BCCFA 2015). They were reported to have contributed 
about \$1.6 million each to their local economies. In our case, we found that in the most recently reported period (2012/2013 fiscal year), over \$2 000000 was awarded in contracts, and \$285 000 dollars awarded in cash (grants and donations) (WCFC End of Year Summary 2012/2013). Our data indicate that the only source of income for the WCFC is through the sale of logs, and that the WCFC has not diversified its operations, such as processing logs, to create other sources of income. This limited diversity of economic activity is consistent with the findings of Teitelbaum (2014) and Furness et al. (2015). In fact, Furness et al. (2015, p.88) highlight that "...only two organizations had developed valueadded manufacturing, and only eight organizations had more than one source of revenue from their tenure, while the remaining 30 relied solely on harvesting trees to be sold on the log market."

Ensuring species diversity and forest health are important ecological indicators of SFM in BC and Canada (Table 2). WCFC participants and documents indicated they have taken steps to address both indicators. The WCFC's action on species diversity is reflected in planting non-target trees that are not considered ecologically suited to the Bulkley Valley in anticipation of climate change, such as western larch, Douglas-fir, and western redcedar, in addition to lodgepole pine, Engelmann spruce and balsam fir, which are the main species found in the landbase. Moreover, recovering endangered species is a component of species diversity (MFML 2010), which the WCFC is addressing with its efforts to support the recovery of whitebark pine.

Regarding forest health, the organisation is learning from its present management practices and also looking to develop new forest management practices following its climate change experiment with the CNC and NWCC. Results from the experiment may impact current forest management approaches in an effort to improve forest health and resiliency - the overarching goal of WCFC's IRM initiative. The challenge with the IRM initiative, however, is that its progress has been somewhat negatively affected because the member who spearheaded the initiative has left the Board. Furness et al. (2015) indicate that generally, CFs in BC (with or without an environmental agenda) see forest stewardship as an important component of their management and therefore are responsive to environmental concerns. Of the $38 \mathrm{CFs}$ they surveyed, only one did not recognise forest stewardship as central to their operations.

Actions such as paying contractors to protect forest understory, leaving buffers in areas not required by law, and leaving larger buffers along riparian zones because of the Wet'suweten interest, all speak to the fact that WCFC is active in supporting ecological sustainability. Riparian zone management is an important consideration in water management and essential to SFM in Canada (Table 2).

Climate change has been identified as a factor that significantly affects the measurement, assessment, and monitoring of SFM in BC (MFML 2010), and therefore mitigating its impact through management is recommended. This makes WCFC's collaboration on the climate change experiment an important effort towards achieving sustainability on the landbase. By planting the non-target species, the WCFC is managing for some uncertainties in forest management and providing data that may be useful to others.
Though the WCFC has taken action on SFM in the theme areas identified in Table 2, one important deficiency noted by participants is that the WCFC has not developed local C\&I to assess outcomes associated with the actions they have taken to advance SFM. This presents a challenge in that there is no baseline against which to measure actions and assess outcomes. Given this deficiency, we were not able to establish whether the actions taken by WCFC were adequate; rather, we were only able to describe them from the perspectives of those involved. It is also not possible for us to measure how well WCFC is meeting the government of BC and the CCFM criteria established in Table 2, because there are no firm measures of what progress on each of these should look like. We can only say that the WCFC has made efforts in relation to each of these, which can be assessed against some arbitrary benchmark or against the efforts of other CFs.

Some participants identified constraints posed by the Community Forest Agreement and provincial policies which prevent the WCFC from being innovative in relation to SFM, particularly in relation to how the landbase is managed. For instance, with NTFP management, the CFA does not automatically transfer rights to communities to access these forest resources (Mcllveen and Bradshaw 2005/2006), nor does it grant CFs exclusive rights to harvest them (Davis 2011). This could account for the minimal efforts at managing NTFPs by WCFC. Another reason is that the Wet'suweten are not pushing for the commercialisation of NTFPs.

In addition, some participants noted that $\mathrm{CFs}$ are required to satisfy the same requirements enshrined in the FRPA as traditional industrial forest licensees. Thus, opting to do things differently on the land (such as planting more non-target species) might result in a fine. These explanations are supported by Ambus and Hoberg (2011, p. 945), who conclude that "with a few relatively minor exceptions, the CFA is a small version of the large industrial area-based tenure, the Tree Farm License". Thus, the CFA, by its design, does not necessarily provide the flexibility required by communities to take innovative approaches to SFM, nor does it fully provide communities with the autonomy to manage the forest for their benefit (Ambus and Hoberg 2011). While CFs in BC are committed to balancing forest management with managing non-timber forest values, this is not often achieved because of policy and the market environment in BC (Furness et al. 2015).

\section{Conclusions}

The data we collected from WCFC showed action across sixteen different areas of SFM, covering in some way each of the three main themes of SFM noted in the literature and a fourth theme of cultural sustainability. WCFC has made strides in relation to the social dimensions of sustainability in their work with the Wet'suweten and forest user groups. On the economic front, they have also developed an approach for sharing profits when they exist, and are managing for some of the ecological components of the forest, such as biodiversity and wildlife. With regards to cultural sustainability, specific efforts are directed towards protecting cultural features and values on the landbase. Nonetheless, their noted public participation efforts in relation to SFM while evident, need to be supplemented with a clear program/plan that aims to involve a more diverse 'public' in the management of the $\mathrm{CF}$ tenure. 


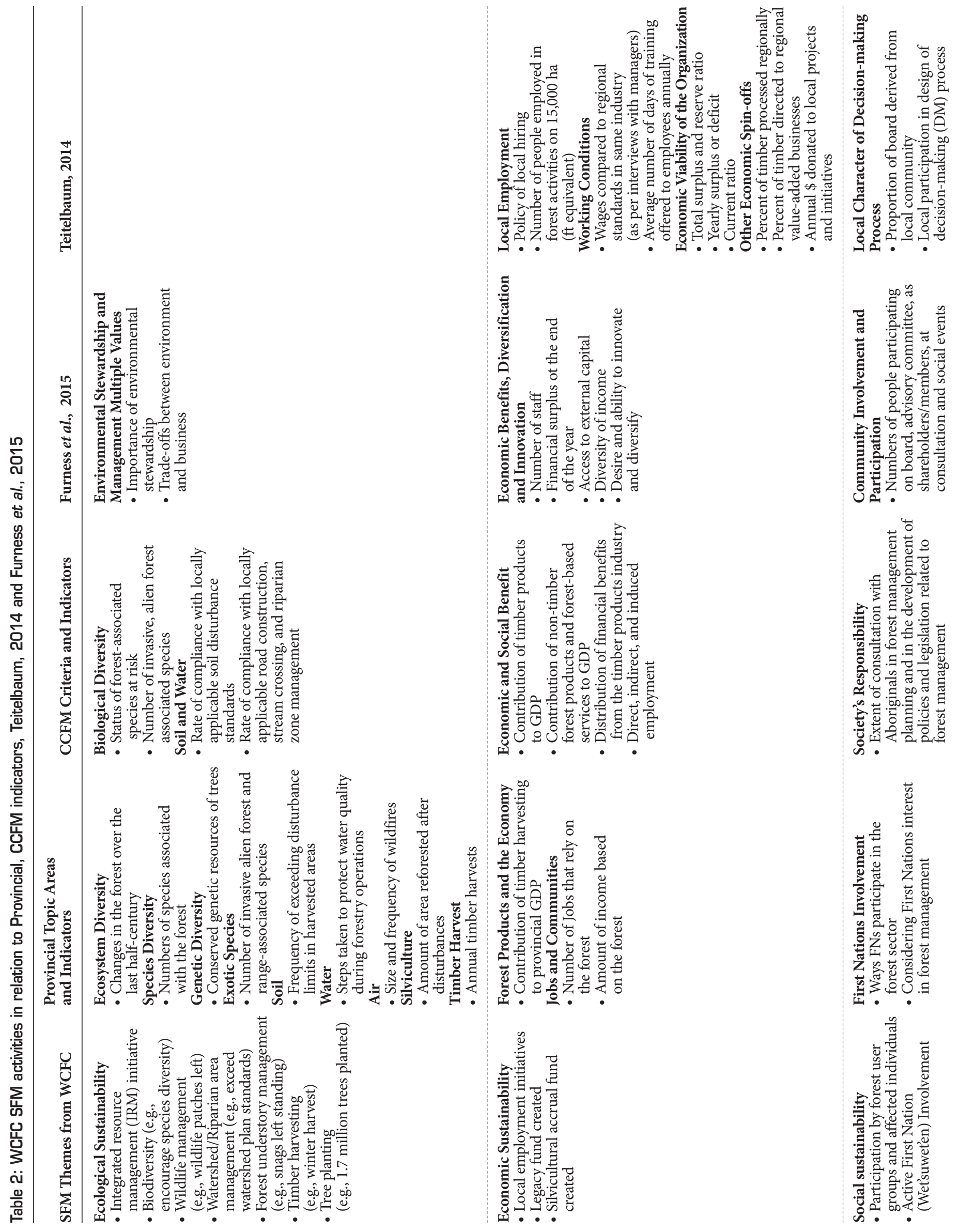




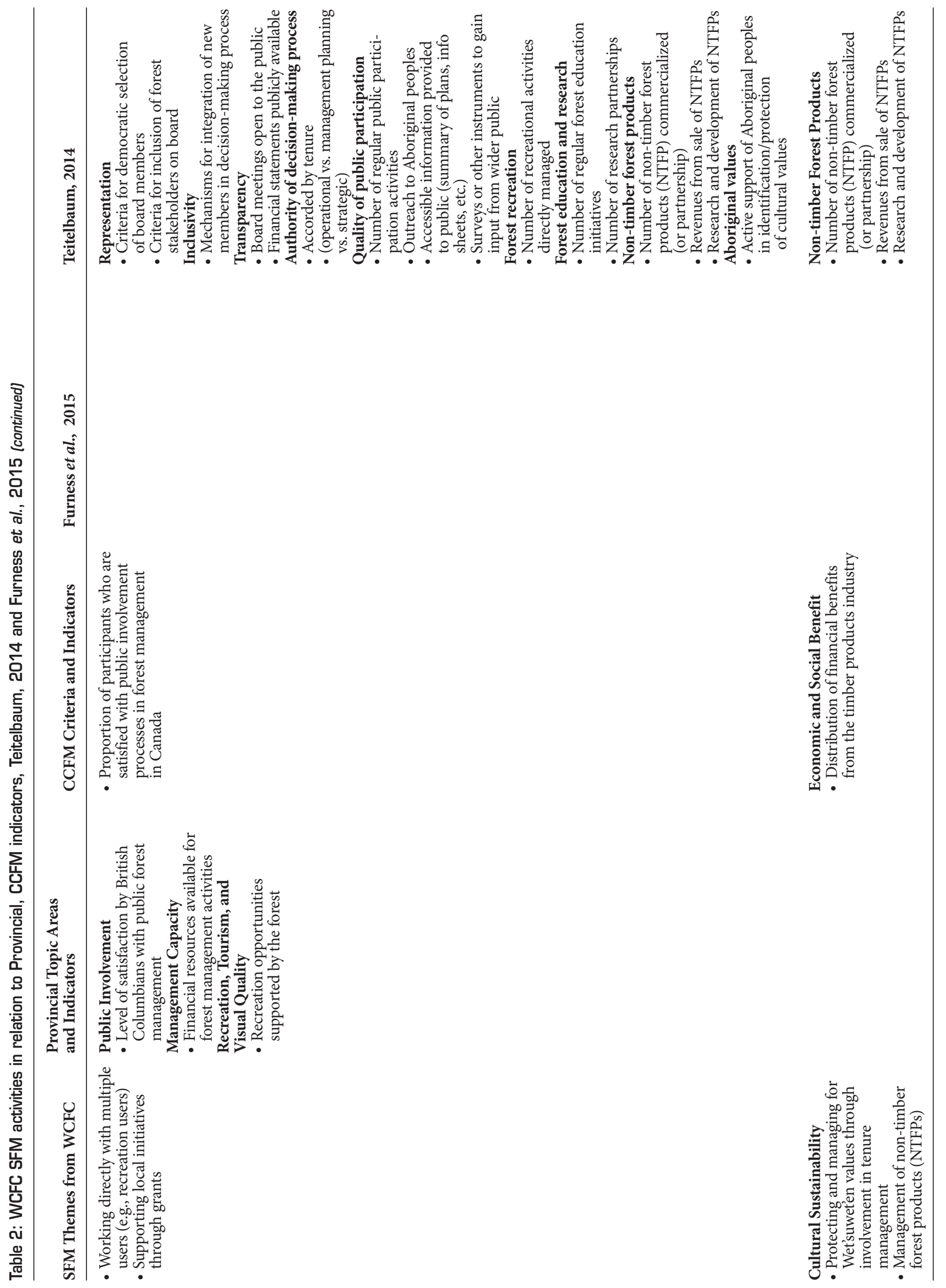


The data we collected are not sufficient to allow any conclusion as to whether the SFM outcomes are adequate. Considering them against the 91 indicators developed by the $\mathrm{BC}$ government, the CCFM C\&I, and the C\&I developed for measuring CF outcomes by Teitelbaum (2014) and Furness et al. (2015), the outcomes do appear to be modest. In fact, beyond the distribution of local benefits, development of an integrated resource management initiative, establishing a legacy fund, and the involvement of the Wet'suwet'en, which led to actions to protect their cultural values, little can be said about how innovative the WCFC has been in advancing the SFM agenda. Both the strong policy environment in BC and the limited capacity of CFs may hinder CFs from taking innovative approaches to managing their tenure. CFs face the difficulty of being subjected to the same regulations as industrial forests that have larger capacities and advantages in economies of scale. Moreover, the lack of clear C\&I for measuring SFM outcomes of small-scale tenures such as CFs does not provide researchers with a framework against which their performance can be evaluated or assessed. For instance, translating and applying measures of SFM developed for the provincial and national scales to CFs is very challenging. BC has a daunting 91 indicators over 24 topic areas. These indicators were usually developed for industrial forestry, and in some cases clearly do not apply in a local context (e.g., effectiveness of law in achieving SFM, area of forest land owned by Aboriginal people). This is due in part to the limited capacity of CFs and the small size of their operations. In this regard, Teitelbaum's indicators provided the most direction and clarity on what specific indicators (e.g., mechanisms for integrating new members, amount of wood processed locally) could be applied to the criteria she developed. Even so, the indicators Teitelbaum developed do not address the ecological outcomes of community forestry.

Consequently, this paper underscores the importance of encouraging CF management boards to develop local level indicators that will allow them to track the sustainability of their operations. Maintaining the good health of the forest, for example, is essential in small-scale operations to ensure sustainability. In this regard, our research supports and extends research undertaken by Teitelbaum (2014) and Furness et al. (2015). In order to gain reliable information, the performance of CFs needs to be measured against a set of C\&I developed by the local community affected and in concert with the requirements of the provincial government. If the sixteen themes we identified from the data collected for the study were adopted by CFs as clear and independent indicators of progress, it would be an important contribution to SFM locally in benchmarking some criteria and establishing them for future use. It could also aid in the problem of selfreporting bias from which most research on indicators of community forestry progress suffers. This effort may also help the provincial government and/or umbrella CF organisations in BC to develop SFM frameworks that make sense for $\mathrm{CF}$ operations. The CF approach differs from industrial forestry in that forests are managed to ensure that the goals of SFM are met locally. All measures of progress should reflect this difference.

This paper also provides a first step in examining the contributions of the CF approach to SFM in a Canadian context. We note that our data, collected in one study location within a narrow time period, limits its general application. However, it offers a first step in encouraging CFs to identify and adopt C\&I for SFM that are situation-specific, readily tracked, and locally-meaningful. As a relatively new forest governance approach, CF boards must adopt such empirical-based assessments that can support their claims to being 'better' than other management systems such as industrial forestry. Data from such studies will not only be useful for policymakers in BC for assessing CF practice, but will be vital to other jurisdictions that are considering or or may consider the CF model.

In our study, we observed that the CF approach provides potential opportunities to sustainably manage the forest, since it is local and involves the people most impacted by poor forest management practices. These people can share ideas and information, collaborate on projects, and help manage the forest in ways that improve the wellbeing of both the people and the forests. We suggest that in future studies, performance by CFs be measured against local indicators developed around those established by BC and the CCFM. In addition, future research could compare CFs to other tenures in the province in order to determine the relative contributions of each to achieving the goals of SFM.

\section{References}

Adam M.C. and D. Kneeshaw. 2009. Formulating Aboriginal Criteria and Indicator Frameworks. Sustainable Forest Management Network, Edmonton, Alberta.

Alemagi, D. 2010. A comparative assessment of community forest models in Cameroon and British Columbia, Canada. Land Use Policy 27(3): 928-936.

Ambus, L. and G. Hoberg. 2011. The evolution of devolution: A critical analysis of the Community Forest Agreement in British Columbia. Society and Natural Resources: An International Journal 24(9): 933-950.

Baker, M. and J. Kusel. 2003. CF in the United States: Learning from the past, crafting the future. Island Press, Washington D.C.

Bass, S. 2002. Application of criteria and indicators to support sustainable forest management: Some key issues. In Raison, R.J., A. G. Brown and D.W. Flinn. (eds.), Criteria and Indicators for Sustainable Forest Management. IUFRO Research Series, vol. 7. CABI Publishing, Oxford, pp. 19-37.

Beckley, T. 1998. Moving toward consensus-based forest management: A comparison of industrial, co-managed, community and small private forests in Canada. Forest. Chron. 74(5): 736-744.

Berkes, F. 2009. Evolution of co-management: Role of knowledge generation, bridging organizations and social learning. J. Environ. Manage. 90(5):1692-1702.

Bradshaw, B. 2003. Questioning the credibility and capacity of community-based resource management. Can. Geogr. 47(2): 137-150.

British Columbia Ministry of Forests, Mines and Lands. 2010. The state of BritishColumbia's Forests. 3rd ed. Forest Practices and Investment Branch, Victoria, B.C.

British Columbia Ministry of Forests, Land and Natural Resource Operations. 2014. Community Forest Agreements. Available from: https://www.for.gov.bc.ca/hth/timber-tenures/community/index.htm British Columbia Community Forest Association. 2015. Community Forest Indicators 2014: Measuring the Benefits of CF. Available from: BCCFA_Report_2014_medium_file_A_1.pdf

Bullock, R. and K. Hanna. 2008. CF: mitigating or creating conflict in British Columbia? Society and Natural Resources: An International Journal 21(1): 77-85.

Canadian Forest Service. 2001. The state of Canada's forests 20002001: Sustainable Forestry: A reality in Canada. Natural Resources Canada, Canadian Forest Service, Ottawa, ON. 
Canadian Council of Forest Ministers. 2006. Criteria and indicators of sustainable forest management in Canada: 2005 National status. Cat. no. Fo4-8/2005E

Canadian Council of Forest Ministers. 2008. Measuring our progress: Putting sustainable forest management into practice across Canada and beyond. Fo4-26/2008E-PDF

Charnley, S. and R.P. Poe. 2007. CF in theory and practice: Where are we now? Annu. Rev. Anthropol. 36: 301-336.

Creswell, J.W. 2014. Research design: Qualitative, quantitative, and mixed methods approaches. Sage Publications: Los Angeles.

Davis, E.J. 2011. Non-timber forest product development in British Columbia's community forests and small woodlands: Constraints and potential solutions. B.C. Ministry of Forest and Range, Forest Science Program; and Centre for Livelihoods and Ecology, Royal Roads University, Victoria, B.C. Land Management Handbook 67.

Duinker, P., P. Matakala and D. Zhang. 1991. CF and its implications for Northern Ontario. Forest. Chron. 67(2):131-135.

Duinker, P., N.P. Matakala, F. Chege and L. Bouthillier. 1994. Community forests in Canada: An overview. Forest. Chron. 70(6): 711-719.

Furness, E., H. Harshaw and H. Nelson 2015. CF in British Columbia: Policy progression and public participation. Forest Policy Econ. 58: 85-91.

Hickey, G.M. and J.L. Innes. 2008. Indicators for demonstrating sustainable forest management in British Columbia, Canada: An international review. Ecol. Indic. 8 (2): 131- 140.

McDonald, G.T. and M.B. Lane. 2004. Converging global indicators for sustainable forest management. Forest Policy Econ. 6(1): 63-70. McGurk, B., A.J. Sinclair and A. Diduck. 2006. An assessment of stakeholder advisory committees in forest management: Case studies from Manitoba, Canada. Society and Natural Resources: An International Journal 19 (9): 809-826.

McIlveen, K. and B. Bradshaw. 2005/2006. A preliminary review of British Columbia's community forest pilot project. Western Geography 15/16: 68-84.

Natural Resources Canada. 2012. The State of Canada's Forest: Annual Report 2012. Available from: FO1-6/2012E-PDF
Parkins, J.R., S. Nadeau, L. Hunt, J. Sinclair, M. Reed and S. Wallace. 2006. Public participation in forest management: Results from a national survey of advisory committees. Nat. Resour. Can., Can. For. Serv., North, For. Cent., Edmonton, AB. Inf. Rep. NOR-X-409. Pokharel, R.K. and M. Suvedi. 2007. Indicators for measuring the success of Nepal's community forestry program: Local perspective. Hum. Ecol. Rev. 14 (1): 68-75.

Pokharel, R.K., P.R. Neupane, K.R. Tiwari and M. Köhl (2015). Assessing the sustainability in community based forestry: A case from Nepal. Forest Policy Econ. 58: 75-84

Ritchie, B., McDougall, C., Haggith, M., de Oliviera, N.B., 2000. Criteria and Indicators of Sustainability in Community Managed Forest Landscapes: An Introductory Guide. Center for International Forestry Research, Bogor.

Sherry, E., R. Halseth, G. Fondahl, M. Karjala and B. Leon. 2005. Local-level criteria and indicators: An Aboriginal perspective on sustainable forest management. Forestry: An International Journal of Forest Research 78(5): 513-539.

Teitelbaum, S. 2014. Criteria and indicators for the assessment of CF outcomes: A comparativeanalysis from Canada. J. Environ. Manage. 132: 257-267.

Teitelbaum, S., T. Beckley and S. Nadeau. 2006. A national portrait of CF on public land in Canada. Forest. Chron. 82(3): 416-428.

Thomas, G. 2011. A typology for the case study in social science following a review of definition, discourse, and structure. Qual. Inq. 17(6): 511-521.

Wijewardana, D. 2008. Criteria and indicators for sustainable forest management: The road travelled and the way ahead. Ecol. Indic. 8(2): 115-122.

Wetzin'kwa Community Forest Corporation End Year Summary. 2008/2009.

Wetzin'kwa Community Forest Corporation End Year Summary. 2012/2013.

Yin, R.K. 2003. Case study research: Design and methods. Sage Publications, Thousand Oaks, California. 